\section{Personal and behavioral factors associated with
bicycling in adults from Curitiba, Paraná State, \\ Personal and behavioral factors associated with
bicycling in adults from Curitiba, Paraná State, Brazil}

\author{
Fatores individuais e comportamentais associados \\ ao uso de bicicleta em adultos de Curitiba, \\ Paraná, Brasil
}

\author{
Factores individuales y comportamentales \\ asociados con el uso de la bicicleta en adulto \\ de Curitiba, Paraná, Brasil
}




\section{Introduction}

Bicycling has the potential to promote numerous health benefits, including better cardiorespiratory fitness and a decreased risk of developing cardiovascular disease 1,2 and being overweight or obese 3 . Moreover, this mode of transportation may help to reduce physical inactivity 4 , which is a leading cause of death worldwide 5 and to reduce congestion, carbon emissions and the consumption of fossil fuels 6 . Despite these benefits, the use of the bicycle for transportation and leisure is low, both in highincome countries 7,8 and in low- and middleincome countries 9,10. In Brazil, an estimated 8 to $16 \%$ of adults commute by bicycle 11 , a prevalence similar to that of Canada 7,12,13 and Australia 8 but lower than in European countries $14,15,16$. The use of the bicycle in leisure time is one of the five most common forms of physical activity among Brazilian adults 17. Data from other countries show a wide variation. For example, between 9.7 and $42 \%$ of adults report using a bicycle during leisure time in Australia $8,18,19$, while one in of four adults in the United States and Europe do so 4.

In fact, personal, behavioral and environmental factors are associated with bicycling for leisure time and transportation 8,20. In highincome countries, bicycling is more frequent among men $8,9,13,18$, younger adults 12 , low socioeconomic status groups 13,21 and those reporting good health 15 . However, data from low and middle-income countries is scarce. Economic and social aspects, such as a larger low income population 9,22 , social norms that do not value the bicycle as a means of transportation, the aggressive behavior of drivers 19 and a lack of facilities for bicycling 23 may present challenges to the promotion of bicycling in these countries. To identify the correlates of bicycling will help to improve interventions, programs and policies aiming at promoting the adoption of bicycling 24 . Thus, this study aims to investigate the association of personal and behavioral traits with bicycling for transportation and leisure in adults from Curitiba, Paraná State, Brazil.

\section{Methods}

The results of this study are part of the ESPAÇOS Project 25 which was conducted in Curitiba, in 2010. The ESPAÇOS Project was a cross-sectional survey conducted in census tracts selected according to walkability and income characteristics. The study included 16 census tracts with high walkability (eight low-income and eight high-income census tracts) and 16 with low walkability (eight low-income and eight high-income census tracts). After power estimations a minimum sample of 22 individuals per census tract was adopted ( $\mathrm{n}=704$ persons; $50 \%$ women). For the selection of households, all were visited and a total of 10,063 households were identified (average-314 \pm 111 households per census tract). Within each census tract the households were systematically selected from a list of all eligible households. Among the selected participants ( $\mathrm{n}=$ 704) a total of 699 participants (53.1\% women), completed all interviews. The overall success rate was $66.4 \%$ and was higher in high-income census tracts $(71.2 \%$ and $70.9 \%)$ compared to low-income ones $(62.6 \%$ and $62.3 \%)$, while the overall refusal rate was $29.5 \%$, which was similar between the strata $\left(\chi^{2}=5.09 ; p=0.165\right)$. Further details about census tract selection, sample design and data collection can be obtained elsewhere 25 . Participants were adults aged between 18 and 65 years who had lived in the neighborhood for at least one year. Individuals with physical disabilities and domestic staff were ineligible for the study 25 . The study was approved by the Ethics Committee of the Pontifícia Universidade Católica do Paraná, Brazil (protocol n. 3034/2009).

Bicycling for transportation and leisure was assessed by self-report according to the frequency (days per week) and time (minutes per day) using the International Physical Activity Questionnaire (IPAQ) 26. The questions were pilot-tested, and the test-retest agreement (95.5 and $97 \%$ ) and intraclass correlation coefficient (0.82 and 0.74) were deemed suitable for the study.

The data collected included gender, age, marital status (single, separated, widowed, married, or living with a partner), children (yes/no), education (elementary school, high school or university degree), and work status (yes/no). Socioeconomic status was determined according to the assets within the household and family education 27 and was categorized into three levels (high, medium or low). The individuals were also asked about bicycle and car ownership (yes/ no). Bicycling and walking for transportation and leisure time physical activity were assessed through the IPAQ-long version, which was validated for the Brazilian population 28. The participants reported the frequency (day/week) and duration (minutes/day) of walking and moderate-intensity and vigorous-intensity physical activity. The physical activity level was obtained by summing the time for walking and moderate and vigorous physical activity (which is multiplied by two) 29 . The individuals were classified 
as inactive ( $<10$ minutes/week), insufficiently active (10 to 149 minutes/week) or active ( $\geq 150$ minutes/week) 29. Finally, perceptions about quality of life and general health conditions were assessed using the World Health Organization Quality of Life Instrument (WHOQOL-8) 30.

Double data entry was used with Epidata 3.1 (Epidata Assoc., Odense, Denmark). Absolute and relative frequencies and the chi-square test were used to describe the sample. The associations between bicycling for transportation and in leisure time with the independent variables were analyzed using a Poisson regression. Initially, the association between each independent variable with bicycling outcomes was tested (bivariate analyses), and all variables were used in the multivariable models. All analyses were conducted using Stata 11.1 (Stata Corp., College Station, USA), and the final models considered a significance level of $5 \%$.

\section{Results}

The study included 704 adults $(53.1 \%$ female) between 18 and 65 years old $(66.4 \%$ of success rate) 25 . After checking for missing data, 27 adults (3.8\%) were excluded, and the final analytical sample was made up of 677 subjects. Bicycling for transportation and in leisure time was reported by $11.2 \%$ (95\%CI: $9.0-14.0)$ and $16.7 \%$ (95\%CI: 14.0-20.0) of the sample, respectively. Overall, men reported more frequent bicycling for transportation ( $19.1 \%$ men, $4.2 \%$ women; $\mathrm{p}<0.001)$ and in leisure time $(25.3 \%$ men, $9 \%$ women; $\mathrm{p}<0.001)$ than did women. Additionally, men also reported higher bicycle ownership (49.1\% men, $37.3 \%$ women; $p=0.002$ ), socioeconomic status ( $13.4 \%$ men, $9.8 \%$ women; $\mathrm{p}=0.011)$, car ownership (82.2\% men, $70.9 \%$ women; $\mathrm{p}=0.001$ ), positive perception of quality of life (78.4\% men, $67.2 \%$ women; $p=0.001)$ and positive perception of health $(76.9 \%$ men, $67.2 \%$ women; $p=0.005$ ) than did women. Other sociodemographic characteristics of the sample are presented in Table 1.

Overall, bicycling in leisure time was more frequent among men, young adults, bicycle owners, physically active individuals and those with a positive perception of their health (Table 2). In the multivariable analysis, bicycling in leisure time was higher among men $(\mathrm{PR}=2.08$; $95 \% \mathrm{CI}$ : $1.66-2.60 ; \mathrm{p}<0.001)$, young adults $(<30$ years old: $\mathrm{PR}=2.03$; 95\%CI: $1.25-3.30 ; \mathrm{p}=0.006 ; 30.0$ to 39.9 years: $\mathrm{PR}=1.64$; 95\%CI: $1.02-2.62 ; \mathrm{p}=0.03)$, bicycle owners $(\mathrm{PR}=8.76$; 95\%CI: 4.86-15,78; $\mathrm{p}<$ $0.001)$ and physically active individuals $(\mathrm{PR}=$ 2.41; 95\%CI: 1.50-3.87; $\mathrm{p}=0.001$ ).
In the bivariate analysis (Table 3), most of the variables were associated with bicycling for transportation. After adjusting for all confounding variables, men ( $\mathrm{PR}=3.63$; 95\%CI: 2.45-5.35; $\mathrm{p}<0.001)$, bicycle owners ( $\mathrm{PR}=10.2$; 95\%CI: 5.35-19.58; $\mathrm{p}<0.001)$, those aged between 30 and $39.9(\mathrm{PR}=1.68 ; 95 \% \mathrm{CI}: 1.04-2.73 ; \mathrm{p}=0.034)$, those of low socioeconomic status $(\mathrm{PR}=5.00$; 95\%CI: 1.65-15.17; $\mathrm{p}=0.006$ ), and those with a negative perception of their quality of life (PR = 1.59; 95\%CI: 1.04-2.43; $\mathrm{p}=0.033$ ) reported using a bicycle for transportation more frequently.

\section{Discussion}

The results of this study demonstrate the personal and behavioral aspects that are associated with bicycling in Curitiba. The analyses were conducted for separate bicycling outcomes (e.g., leisure and transportation), which, to the best of the authors' knowledge, has not previously been explored in low or middle-income countries. Bicycling was more frequent for leisure than for transportation (16.7\% for leisure, $11.2 \%$ for transportation; $\mathrm{p}<0.001)$. Only one in five individuals (17.7\%) demonstrated behavior related to the use of a bicycle as a form of physical activity in leisure time. This result is similar to that reported in Australia (19\%) but lower than that found in the Netherlands (27.2\%) 4,18. The prevalence of using a bicycle for transportation (11.2\%) was similar to that found in other studies in Brazil 11,31; however, the prevalence was lower than in European cities (prevalence $39.7 \%$ to $67.5 \%$ ) 4,16 . This difference may be attributed to environmental and social characteristics that can encourage or inhibit bicycling. For example, countries like the Netherlands and Denmark have a wide road network dedicated to bicycling that is integrated with the public transportation system ${ }^{32}$. Moreover, the availability of squares, parks and streets with bicycle path facilitates encourage the use of bicycling for leisure time 18,32 . On the other hand, in low- and middle-income countries, such facilities are not a priority 11. Furthermore, social aspects such as a lack of public security are barriers for cyclists. For instance, one study found that a community's perception of dangerous surroundings was correlated with greater adult physical inactivity 33 .

These aspects can significantly contribute to a lower use of bicycling during leisure time. In this study, men cycled for leisure time more often than did women. Evidence suggests that women perceived more barriers to physical activities 19 and activities of a moderate and vigorous intensity. Moreover, women report less confidence 
Table 1

Characteristics of the study participants according to gender. Curitiba, Paraná State, Brazil ( $N=677)$.

\begin{tabular}{|c|c|c|c|c|c|c|c|}
\hline \multirow[t]{2}{*}{ Variables/Categories } & \multicolumn{2}{|c|}{ Male } & \multicolumn{2}{|c|}{ Women } & \multirow[t]{2}{*}{$p$-value } & \multicolumn{2}{|c|}{ Total } \\
\hline & $\mathbf{n}$ & $\%$ & $\mathrm{n}$ & $\%$ & & n & $\%$ \\
\hline \multicolumn{8}{|l|}{ Age (years) } \\
\hline$<30.0$ & 89 & 27.8 & 73 & 20.4 & 0.013 & 162 & 23.9 \\
\hline $30.0-39.9$ & 72 & 22.5 & 84 & 23.5 & & 156 & 23.0 \\
\hline $40.0-49.9$ & 77 & 24.1 & 79 & 22.1 & & 156 & 23.0 \\
\hline$\geq 50.0$ & 82 & 25.6 & 121 & 33.9 & & 203 & 30.0 \\
\hline \multicolumn{8}{|l|}{ Marital status } \\
\hline Single/Separated/Widowed & 137 & 42.8 & 146 & 40.9 & 0.614 & 283 & 41.8 \\
\hline Married/Living with a partner & 183 & 57.2 & 211 & 59.1 & & 394 & 58.2 \\
\hline \multicolumn{8}{|l|}{ Children } \\
\hline No & 119 & 37.2 & 84 & 23.5 & $<0.001$ & 203 & 30.0 \\
\hline Yes & 201 & 62.8 & 273 & 76.5 & & 474 & 70.0 \\
\hline \multicolumn{8}{|l|}{ Socioeconomic status } \\
\hline Low & 103 & 32.2 & 147 & 41.2 & 0.011 & 250 & 36.9 \\
\hline Medium & 174 & 54.4 & 175 & 49.0 & & 349 & 51.6 \\
\hline High & 43 & 13.4 & 35 & 9.8 & & 78 & 11.5 \\
\hline \multicolumn{8}{|l|}{ Education } \\
\hline Elementary school & 79 & 24.7 & 117 & 32.8 & 0.084 & 196 & 29.0 \\
\hline High school & 110 & 34.4 & 104 & 29.1 & & 214 & 31.6 \\
\hline Higher education & 131 & 40.9 & 136 & 38.1 & & 267 & 39.4 \\
\hline \multicolumn{8}{|l|}{ Own bicycle } \\
\hline No & 163 & 50.9 & 224 & 62.7 & 0.002 & 387 & 57.2 \\
\hline Yes & 157 & 49.1 & 133 & 37.3 & & 290 & 42.8 \\
\hline \multicolumn{8}{|l|}{ Own car } \\
\hline No & 57 & 17.8 & 104 & 29.1 & 0.001 & 161 & 23.8 \\
\hline Yes & 263 & 82.2 & 253 & 70.9 & & 516 & 76.2 \\
\hline \multicolumn{8}{|l|}{ Quality of life } \\
\hline Negative & 69 & 21.6 & 117 & 32.8 & 0.001 & 186 & 27.5 \\
\hline Positive & 251 & 78.4 & 240 & 67.2 & & 491 & 72.5 \\
\hline \multicolumn{8}{|l|}{ Health perception } \\
\hline Negative & 74 & 23.1 & 117 & 32.8 & 0.005 & 191 & 28.2 \\
\hline Positive & 246 & 76.9 & 240 & 67.2 & & 486 & 71.8 \\
\hline \multicolumn{8}{|l|}{ Working status (days/week) } \\
\hline Does not work & 35 & 10.9 & 117 & 32.8 & $<0.001$ & 152 & 22.5 \\
\hline $1-5$ & 158 & 49.4 & 156 & 43.7 & & 314 & 46.4 \\
\hline$>6$ & 127 & 39.7 & 84 & 23.5 & & 211 & 31.2 \\
\hline \multicolumn{8}{|l|}{ Physical activity } \\
\hline Inactive & 44 & 13.8 & 40 & 11.2 & 0.002 & 84 & 12.4 \\
\hline Insufficiently active & 79 & 24.7 & 113 & 37.3 & & 212 & 31.3 \\
\hline Active & 197 & 61.6 & 184 & 51.5 & & 381 & 56.3 \\
\hline \multicolumn{8}{|l|}{ Bicycling for transportation } \\
\hline No & 259 & 80.9 & 342 & 95.8 & $<0.001$ & 601 & 88.8 \\
\hline Yes & 61 & 19.1 & 15 & 4.2 & & 76 & 11.2 \\
\hline \multicolumn{8}{|l|}{ Bicycling during leisure time } \\
\hline No & 239 & 74.7 & 325 & 91.0 & 0.001 & 564 & 83.3 \\
\hline Yes & 81 & 25.3 & 32 & 9.0 & & 113 & 16.7 \\
\hline
\end{tabular}

Note: values in bold indicate significant association: $p<0.05$. 
Table 2

Factors associated with bicycling during leisure time among adults. Curitiba, Paraná State, Brazil $(\mathrm{N}=677)$.

\begin{tabular}{|c|c|c|c|c|c|c|c|c|}
\hline \multirow[t]{2}{*}{ Variables/Categories } & \multicolumn{2}{|c|}{ Leisure time bicycling } & \multicolumn{3}{|c|}{ Crude analysis } & \multicolumn{3}{|c|}{ Adjusted analysis * } \\
\hline & $\mathrm{n}$ & $\%$ & PR & $95 \% \mathrm{Cl}$ & p-value & PR & $95 \% \mathrm{Cl}$ & $\mathrm{p}$-value \\
\hline \multicolumn{9}{|l|}{ Gender } \\
\hline Male & 81 & 25.3 & 2.82 & $2.05-3.88$ & $<0.001$ & 2.08 & $1.66-2.60$ & $<0.001$ \\
\hline Female & 32 & 9.0 & Reference & & & Reference & & \\
\hline \multicolumn{9}{|l|}{ Age (years) } \\
\hline $18.0-29.9$ & 39 & 24. 1 & 2.57 & $1.56-4.23$ & 0.001 & 2.03 & $1.25-3.30$ & 0.006 \\
\hline $30.0-39.9$ & 28 & 17.9 & 1.91 & $1.09-3.35$ & 0.024 & 1.64 & $1.02-2.62$ & 0.038 \\
\hline $40.0-49.9$ & 27 & 17.3 & 1.84 & $1.11-3.05$ & 0.018 & 1.39 & $0.89-2.17$ & 0.135 \\
\hline$>50.0$ & 19 & 9.4 & Reference & & & Reference & & \\
\hline \multicolumn{9}{|l|}{ Marital status } \\
\hline Single/Separated/Widowed & 54 & 19.1 & 1.27 & $0.90-1.79$ & 0.161 & 1.1 & $0.74-1.64$ & 0.613 \\
\hline Married/Living with a partner & 59 & 15.0 & Reference & & & Reference & & \\
\hline \multicolumn{9}{|l|}{ Children } \\
\hline No & 40 & 19.7 & 1.27 & $0.92-1.76$ & 0.129 & 1.13 & $0.76-1.69$ & 0.521 \\
\hline Yes & 73 & 15.4 & Reference & & & Reference & & \\
\hline \multicolumn{9}{|l|}{ Economic level } \\
\hline Low & 35 & 14.0 & Reference & & & Reference & & \\
\hline Medium & 62 & 17.8 & 1.26 & $0.87-2.44$ & 0.137 & 1.07 & $0.65-1.75$ & 0.762 \\
\hline High & 16 & 20.5 & 1.26 & $0.90-1.77$ & 0.158 & 1.01 & $0.49-2.11$ & 0.957 \\
\hline \multicolumn{9}{|l|}{ Education } \\
\hline Elementary school & 29 & 14.8 & Reference & & & Reference & & \\
\hline High school & 35 & 16.4 & 1.10 & $0.69-1.75$ & 0.660 & 1.04 & $0.67-1.63$ & 0.830 \\
\hline Higher education & 49 & 18.3 & 1.24 & $0.84-1.82$ & 0.266 & 1.25 & $0.76-2.06$ & 0.352 \\
\hline \multicolumn{9}{|l|}{ Own bicycle } \\
\hline No & 13 & 3.4 & Reference & & & Reference & & \\
\hline Yes & 100 & 34.5 & 10.26 & $5.80-18.14$ & $<0.001$ & 8.76 & $4.86-15.78$ & $<0.001$ \\
\hline \multicolumn{9}{|l|}{ Own car } \\
\hline No & 28 & 17.4 & 1.05 & $0.71-1.56$ & 0.780 & 1.47 & $0.89-2.42$ & 0.119 \\
\hline Yes & 85 & 16.5 & Reference & & & Reference & & \\
\hline \multicolumn{9}{|l|}{ Quality of life } \\
\hline Negative & 26 & 14.0 & Reference & & & Reference & & \\
\hline Positive & 87 & 17.7 & 1.26 & $0.83-1.92$ & 0.257 & 0.79 & $0.50-1.26$ & 0.323 \\
\hline \multicolumn{9}{|l|}{ Health perception } \\
\hline Negative & 22 & 11.5 & Reference & & & Reference & & \\
\hline Positive & 91 & 18.7 & 1.62 & $0.98-2.68$ & 0.057 & 1.12 & $0.65-1.92$ & 0.654 \\
\hline \multicolumn{9}{|l|}{ Working status (days/week) } \\
\hline Does not work & 22 & 14.3 & Reference & & & Reference & & \\
\hline $1-5$ & 45 & 14.3 & 0.99 & $0.56-1.73$ & 0.971 & 0.63 & $0.35-1.13$ & 0.122 \\
\hline$>6$ & 46 & 21.8 & 1.50 & $0.92-2.44$ & 0.096 & 0.85 & $0.51-1.39$ & 0.508 \\
\hline \multicolumn{9}{|l|}{ Physical activity } \\
\hline Inactive & 5 & 5.9 & 0.74 & $0.27-2.03$ & 0.551 & 0.78 & $0.30-2.03$ & 0.606 \\
\hline Insufficiently active & 17 & 8.0 & Reference & & & Reference & & \\
\hline Active & 91 & 23.9 & 2.97 & $1.77-4.99$ & $<0.001$ & 2.41 & $1.50-3.87$ & 0.001 \\
\hline
\end{tabular}

PR: prevalence ratio; $95 \% \mathrm{Cl}$ : 95\% confidence interval.

* The analysis was adjusted for all other variables.

Note: values in bold indicate significant association: $p<0.05$. 
Table 3

Factors associated with bicycling for transportation among adults. Curitiba, Paraná State, Brazil $(\mathrm{N}=677)$.

\begin{tabular}{|c|c|c|c|c|c|c|c|c|}
\hline \multirow[t]{2}{*}{ Variables/Categories } & \multicolumn{2}{|c|}{ Bicycling for transportation } & \multicolumn{3}{|c|}{ Crude analysis } & \multicolumn{3}{|c|}{ Adjusted analysis * } \\
\hline & $\mathbf{n}$ & $\%$ & PR & $95 \% \mathrm{Cl}$ & p-value & PR & $95 \% \mathrm{Cl}$ & p-value \\
\hline \multicolumn{9}{|l|}{ Gender } \\
\hline Male & 61 & 19.0 & 4.53 & $2.49-8.24$ & $<0.001$ & 3.63 & $2.45-5.35$ & $<0.001$ \\
\hline Female & 15 & 4.2 & Reference & & & Reference & & \\
\hline \multicolumn{9}{|l|}{ Age (years) } \\
\hline $18.0-29.9$ & 22 & 13.6 & 1.72 & $0.87-3.38$ & 0.110 & 1.55 & $0.86-2.78$ & 0.132 \\
\hline $30.0-39.9$ & 21 & 13.4 & 1.7 & $1.04-2.78$ & 0.033 & 1.68 & $1.04-2.73$ & 0.034 \\
\hline $40.0-49.9$ & 17 & 10.9 & 1.38 & $0.60-2.75$ & 0.346 & 1.20 & $0.66-2.17$ & 0.525 \\
\hline$\geq 50.0$ & 16 & 7.9 & Reference & & & Reference & & \\
\hline \multicolumn{9}{|l|}{ Marital status } \\
\hline Single/Separated/Widowed & 36 & 12.7 & 1.25 & $0.78-1.99$ & 0.332 & 1.28 & $0.94-1.75$ & 0.118 \\
\hline Married/Living with a partner & 40 & 10.1 & Reference & & & Reference & & \\
\hline \multicolumn{9}{|l|}{ Children } \\
\hline No & 25 & 12.3 & 1.14 & $0.71-1.81$ & 0.557 & 0.89 & $0.57-1.40$ & 0.624 \\
\hline Yes & 51 & 10.8 & Reference & & & Reference & & \\
\hline \multicolumn{9}{|l|}{ Economic status } \\
\hline Low & 44 & 16.6 & 4.57 & $1.60-13.08$ & 0.006 & 5.00 & $1.65-15.1$ & 0.006 \\
\hline Medium & 29 & 8.3 & 2.16 & $0.73-6.36$ & 0.156 & 2.18 & $0.80-5.93$ & 0.122 \\
\hline High & 3 & 3.9 & Reference & & & Reference & & \\
\hline \multicolumn{9}{|l|}{ Education } \\
\hline Elementary school & 33 & 16.8 & 2.8 & $1.50-5.25$ & 0.002 & 1.35 & $0.68-2.68$ & 0.368 \\
\hline High school & 27 & 12.6 & 2.1 & $1.24-3.57$ & 0.007 & 1.28 & $0.73-2.25$ & 0.369 \\
\hline Higher education & 16 & 6.0 & Reference & & & Reference & & \\
\hline \multicolumn{9}{|l|}{ Own bicycle } \\
\hline No & 8 & 2.1 & Reference & & & Reference & & \\
\hline Yes & 68 & 23.4 & 11.34 & $5.65-22.74$ & $<0.001$ & 10.2 & $5.35-19.5$ & $<0.001$ \\
\hline \multicolumn{9}{|l|}{ Own car } \\
\hline No & 29 & 18.0 & 1.97 & $1.38-2.82$ & 0.001 & 1.23 & $0.94-1.61$ & 0.110 \\
\hline Yes & 47 & 9.1 & Reference & & & Reference & & \\
\hline \multicolumn{9}{|l|}{ Quality of life } \\
\hline Negative & 24 & 12.9 & 1.21 & $0.76-1.93$ & 0.391 & 1.59 & $1.04-2.43$ & 0.033 \\
\hline Positive & 52 & 10.6 & Reference & & & Reference & & \\
\hline \multicolumn{9}{|l|}{ Health perception } \\
\hline Negative & 64 & 13.2 & Reference & & & Reference & & \\
\hline Positive & 12 & 6.3 & 2.09 & $1.13-3.88$ & 0.020 & 1.76 & $0.98-3.14$ & 0.055 \\
\hline \multicolumn{9}{|l|}{ Working status (days/week) } \\
\hline Does not work & 16 & 10.5 & 1.27 & $0.61-2.62$ & 0.506 & 1.59 & $0.95-2.65$ & 0.071 \\
\hline $1-5$ & 26 & 8.3 & Reference & & & Reference & & \\
\hline$>6$ & 34 & 16.1 & 1.94 & $1.23-3.07$ & 0.006 & 1.23 & $0.86-1.77$ & 0.232 \\
\hline \multicolumn{9}{|l|}{ Physical activity } \\
\hline Inactive & 6 & 7.1 & 0.89 & $0.46-1.70$ & 0.719 & 0.79 & $0.42-1.51$ & 0.480 \\
\hline Insufficiently active & 17 & 8.0 & Reference & & & Reference & & \\
\hline Active & 53 & 13.9 & 1.73 & $0.96-3.13$ & 0.067 & 1.43 & $0.89-2.30$ & 0.133 \\
\hline
\end{tabular}

PR: prevalence ratio; 95\% $\mathrm{Cl}$ : 95\% confidence interval.

* The analyses were adjusted for all other variables.

Note: values in bold indicate significant association: $p<0.05$ 
in navigating and maintaining bicycles than do men 19 . These aspects may partially explain why the young (aged between 18 and 39.9) reported more bicycling compared to other age groups, which is corroborated by the literature 13,18 . These findings may be related to lower physical fitness in the elderly, which may be explained by a decreasing confidence in bicycling with advancing age 34 . The results also show that physically active individuals had a higher rate of bicycling during leisure time 12,35 . Similar results were observed in this study in bicycling for transportation, which was more prevalent among men, and these results are supported by similar studies in Brazil 11,31 and other countries 8,9,19. In part, these results may be explained by women's perceived vulnerability to criminals and violence 19 .

Additionally, middle-aged adults (aged 30 to 39.9 years) reported a higher frequency of bicycling for transportation, which is corroborated by other studies $7,9,12,13$. One hypothesis is that middle-aged adults are more economically active, and bicycles are an efficient and inexpensive way of arriving at work 14,19; however, the lack of information about travel destination prevents the testing of this hypothesis. The proportion of cyclists was higher among those with lower socioeconomic status, which is consistent with the literature 7,12,13,21 and supports the hypotheses presented above. The inverse association between bicycling and the perception of quality of life was unexpected. This result may be due to the positive relationship between income and cycling, which could indicate that low socioeconomic status individuals may be dissatisfied with their general living conditions, regardless of the use of the bicycle. Comparisons with the literature were limited because there is a paucity of work on this subject in low- and middle-income countries. Finally, the ownership of a bicycle was associated with bicycling for both transportation and leisure time, which is similar to results observed in other studies 9,18,35. These findings, which are consistent with the literature, reinforce the importance of access to bicycles as a key step in encouraging their use. Furthermore, the association between bicycling for leisure and meeting physical activity guidelines suggests that bike use could represent an important contribution for adequate levels of physical activity. This is also an important contribution of this paper since most studies on bicycling have mainly analyzed bicycling for transportation.
The study has some limitations. The crosssectional design does not allow for cause and effect to be established. The selection of census tracts in accordance with the levels of walkability and socioeconomic status of the neighborhood may not represent all sectors of Curitiba city. However, the selection of groups with high and low potential environmental and distinct socioeconomic status can minimize this bias. Furthermore, the prevalence of bicycling in the current study was similar to other surveys conducted in Curitiba 10,11. Because only physical activity was included in this study other health behaviors should be included in future studies. The success rate of $66.4 \%$ was somewhat low, however it was even higher than the rates observed in similar studies 36,37 . Additionally, the city of Curitiba has structures for bicycling, such as bike paths connecting public parks, which may contribute to a higher use 38 . Thus, comparison with other cities in Brazil should be made with caution. Environmental factors were not available to be included in the analysis, although they represent important factors for bicycling. Because the survey used self-reported measures of bicycling, the prevalence may have been overestimated. Finally, no information was collected about the commuting distance (e.g. distance and destination), which may be an important confounding factor in the analysis; however, this factor was considered in a different study that showed similar results 22 . Therefore, it is concluded that $\mathrm{Cu}$ ritiba has less bicycling than European cities but rates similar to those of locations in North and Latin America.

The prevalence and factors associated with bicycling were specific to the type of use. It is recommended that programs to encourage bicycling focus on strategies to guarantee access to this modality, such as decreasing the price of bicycles and equipment and focusing more on women and older adults. Recently several tools have been identified to help implement changes to the Brazilian context for making it more conducive for physical activity 39 . The findings from this study highlight the need for such changes in order to promote bicycling in the community. At the individual level, it will be useful to identify the motivational factor and barriers to bicycling in the subgroups identified in this study to tailor interventions more effectively. 


\section{Resumen}

El ciclismo es una forma importante de actividad física, que puede promover beneficios para la salud. El objetivo fue examinar la asociación entre los aspectos personales y de comportamiento en el uso de la bicicleta en el transporte y tiempo libre en adultos. Encuesta de hogares que implica 677 adultos en Curitiba, Paraná, Brasil. La prevalencia de uso de bicicleta fue de un 11,2\% para el transporte y 16,7\% para el ocio. La frecuencia de uso de bicicleta en el tiempo libre fue mayor entre los hombres $(P R=2,08 ; p<0,001)$, individuos con un promedio de edad de 39, 9 años, entre los propietarios de bicicletas $(P R=8,76 ; p<0,001)$ y entre los físicamente activos. El uso de la bicicleta en el transporte fue más frecuente entre los hombres ( $P R=3,63 ; p<0,001)$, con edades entre 30 y 39,9, nivel socioeconómico bajo, con los propietarios de bicicletas $(P R=10,2 ; p<0,001)$ y los que tienen una percepción negativa de calidad de vida. La prevalencia de la bicicleta es baja en Curitiba, teniendo en cuenta su potencial como un medio de actividad física. Los factores personales y conductuales se asocian con cada forma de ciclismo.

Ciclismo; Atividades Recreativas; Locomoción Actividad Motora

\section{Contributors}

M. Kienteka participated in the data analysis and interpretation, drafting the article and transcription of results and final approval of the version to be published. R. S. Reis contributed in the design of the study, critical review of the manuscript, drawing up results and conclusion. C. R. Rech helped to draft the manuscript and to draw up the results and conclusion.

\section{Acknowledgments}

The authors thank the members of the Group on Physical Activity and Quality of Life (PUC-PR), Brazil for helping with the data collection and data control. The authors thank the National Cancer Institute at the National Health Institute for their financial support (NIH R01 CA127296. NCI).

\section{References}

1. Bull FC, Gauvin L, Bauman A, Shilton T, Kohl 3rd HW, Salmon A. The Toronto Charter for Physical Activity: a global call for action. J Phys Act Health 2010; 7:421-2.

2. Oja P, Titze S, Bauman A, de Geus B, Krenn P, Reger-Nash B, et al. Health benefits of cycling: a systematic review. Scand J Med Sci Sports 2011; 21:496-509.

3. Wen LM, Rissel C. Inverse associations between cycling to work, public transport, and overweight and obesity: findings from a population based study in Australia. Prev Med 2008; 46:29-32.

4. Engbers LH, Hendriksen IJ. Characteristics of a population of commuter cyclists in the Netherlands: perceived barriers and facilitators in the personal, social and physical environment. Int J Behav Nutr Phys Act 2010; 7:89.

5. Lee IM, Shiroma EJ, Lobelo F, Puska P, Blair SN, Katzmarzyk PT. Effect of physical inactivity on major non-communicable diseases worldwide: an analysis of burden of disease and life expectancy. Lancet 2012; 380:219-29.

6. Woodcock J, Banister D, Edwards P, Prentice AM, Roberts I. Energy and transport. Lancet 2007; 370:1078-88.
7. Winters M, Friesen MC, Koehoorn M, Teschke K. Utilitarian bicycling: a multilevel analysis of climate and personal influences. Am J Prev Med 2007; 32:52-8.

8. Titze S, Giles-Corti B, Knuiman MW, Pikora TJ, Timperio A, Bull FC, et al. Associations between intrapersonal and neighborhood environmental characteristics and cycling for transport and recreation in adults: baseline results from the RESIDE study. J Phys Act Health 2010; 7:423-31.

9. Cervero R, Sarmiento O, Jacoby E, Gomez LF, Neiman A. Influences of built environments on walking and cycling: lessons from Bogotá. International Journal of Sustainable Transportation 2009; 3:203-26.

10. Parra DC, Hoehner CM, Hallal PC, Ribeiro IC, Reis $\mathrm{R}$, Brownson RC, et al. Perceived environmental correlates of physical activity for leisure and transportation in Curitiba, Brazil. Prev Med 2011; 52:234-8.

11. Reis RS, Hino AAF, Parra DC, Hallal PRC, Brownson RC. Bicycling and walking for transportation in three Brazilian cities. Am J Prev Med 2013; 44:e9-17. 
12. Butler GP, Orpana HM, Wiens AJ. By your own two feet: factors associated with active transportation in Canada. Can J Public Health 2007; 98:259-64.

13. Winters M, Brauer M, Setton EM, Teschke K. Built environment influences on healthy transportation choices: bicycling versus driving. J Urban Health 2010; 87:969-93.

14. de Geus B, De Bourdeaudhuij I, Jannes C, Meeusen R. Psychosocial and environmental factors associated with cycling for transport among a working population. Health Educ Res 2008; 23:697-708.

15. Huy C, Becker S, Gomolinsky U, Klein T, Thiel A. Health, medical risk factors, and bicycle use in everyday life in the over-50 population. J Aging Phys Act 2008; 16:454-64.

16. Hendriksen IJ, Simons M, Garre FG, Hildebrandt $\mathrm{VH}$. The association between commuter cycling and sickness absence. Prev Med 2010; 51:132-5.

17. Malta DCM, Moura EC, Castro AM, Cruz DKA, Morais Neto OL, Monteiro CA. Padrão de atividade física em adultos brasileiros: resultados de um inquérito por entrevistas telefônicas, 2006. Epidemiol Serv Saúde 2009; 18:7-16.

18. Rissel C, Merom D, Bauman A, Garrard J, Wen LM, New C. Current cycling, bicycle path use, and willingness to cycle more-findings from a community survey of cycling in southwest Sydney, Australia. J Phys Act Health 2010; 7:267-72.

19. Heesch KC, Sahlqvist S, Garrard J. Gender differences in recreational and transport cycling: a cross-sectional mixed-methods comparison of cycling patterns, motivators, and constraints. Int J Behav Nutr Phys Act 2012; 9:106.

20. Pikora T, Giles-Corti B, Bull F, Jamrozik K, Donovan R. Developing a framework for assessment of the environmental determinants of walking and cycling. Soc Sci Med 2003; 56:1693-703.

21. Plaut PO. Non-motorized commuting in the US. Transportation Research Part D: Transport and Environment 2005; 10:347-56.

22. Bacchieri G, Gigante DP, Assunção MC. Determinantes e padrões de utilização da bicicleta e acidentes de trânsito sofridos por ciclistas trabalhadores da cidade de Pelotas, Rio Grande do Sul, Brasil. Cad Saúde Pública 2005; 21:1499-508.

23. Tin Tin S, Woodward A, Thornley S, Langley J, Rodgers A, Ameratunga S. Cyclists' attitudes toward policies encouraging bicycle travel: findings from the Taupo Bicycle Study in New Zealand. Health Promot Int 2009; 25:54-62.

24. Sallis JF, Floyd MF, Rodriguez DA, Saelens BE. Role of built environments in physical activity, obesity, and cardiovascular disease. Circulation 2012; 125:729-37.

25. Hino AAF, Rech CR, Gonçalves PB, Hallal PC, Reis RS. Projeto ESPAÇOS de Curitiba, Brasil: aplicabilidade de métodos mistos de pesquisa e informações georreferenciadas em estudos sobre atividade física e ambiente construído. Rev Panam Salud Pública 2012; 32:226-32.
26. Craig CL, Marshall AL, Sjöström M, Bauman AE, Booth ML, Ainsworth BE, et al. International physical activity questionnaire: 12-country reliability and validity. Med Sci Sports Exerc 2003; 35:1381-95.

27. Associação Brasileira de Empresas de Pesquisa. Critério de classificação econômica Brasil. São Paulo: Associação Brasileira de Empresas de Pesquisa; 2010.

28. Matsudo S, Araújo T, Marsudo V, Andrade D, Andrade E. International Physical Activity Questionnaire (IPAQ): study of validity and reability in Brazil. Rev Bras Ativ Fís Saúde 2001; 6:5-18.

29. U.S. Department of Health and Human Services. Physical activity guidelines for Americans. Washington DC: U.S. Department of Health and Human Services; 2008.

30. Power M. Development of a common instrument for quality of life. In: Nasikov A, Gudex C, editors. EUROHIS: developing common instruments for health surveys. Amsterdam: IOS Press; 2003. p. 145-59.

31. Bacchieri G, Barros AJD, Santos JV, Gigante DP. Cycling to work in Brazil: users profile, risk behaviors, and traffic accident occurrence. Accid Anal Prev 2009; 42:1025-30

32. Pucher JB. Making cycling irresistible: lessons from the Netherlands, Denmark, and Germany. Transport Reviews 2008; 28:495-528.

33. Rech CR, Reis RS, Hino AA, Rodriguez-Añez CR, Fermino RC, Gonçalves PB, et al. Neighborhood safety and physical inactivity in adults from Curitiba, Brazil. Int J Behav Nutr Phys Act 2012; 9:72.

34. Cassou AC, Fermino R, Rodriguez-Añez CR, Santos MS, Domingues MR, Reis RS. Barriers to physical activity among Brazilian elderly women from different socioeconomic status: a focus-group study. J Phys Act Health 2011; 8:126-32.

35. Moudon AV, Lee C, Cheadle AD, Collier CW, Johnson D, Schmid TL, et al. Cycling and the built environment, a US perspective. Transportation Research Part D: Transport and Environment 2005; 10:245-61.

36. Heerwegh D, Abts K, Loosveldt G. Minimizing survey refusal and noncontact rates: do our efforts pay off. Surv Res Methods 2007; 1:3-10.

37. Van Dyck D, Cardon G, Deforche B, Sallis JF, Owen N, De Bourdeaudhuij I. Neighborhood SES and walkability are related to physical activity behavior in Belgian adults. Prev Med 2010; 50 Suppl 1:S74-9.

38. Reis RS, Hallal PC, Parra DC, Ribeiro IC, Brownson RC, Pratt M, et al. Promoting physical activity through community-wide policies and planning: findings from Curitiba, Brazil. J Phys Act Health 2010; 7 Suppl 2:S137-45.

39. Pucci GC, Rech CR, Fermino RC, Reis RS. Associação entre atividade física e qualidade de vida em adultos. Rev Saúde Pública 2012; 46:166-79.

Submitted on $26 / \mathrm{Feb} / 2013$

Final version resubmitted on 19/Apr/2013

Approved on 26/Jun/2013 